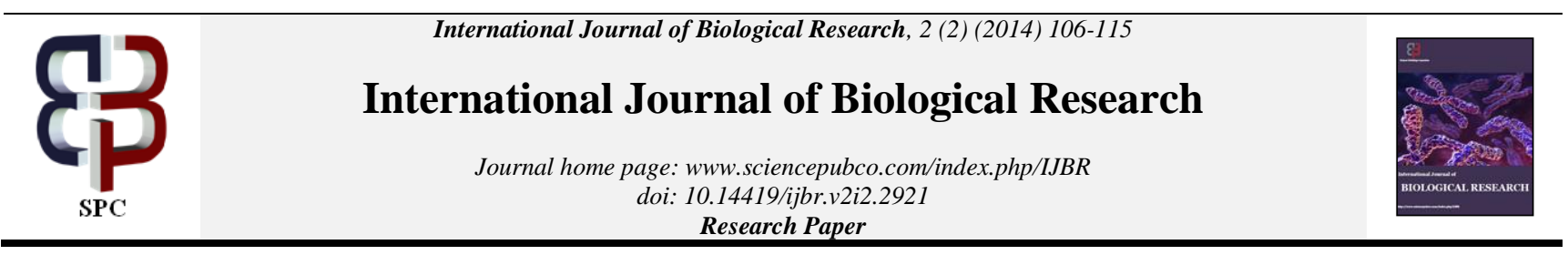

\title{
Study on heavy metals biosorption ability of Saccharomyces cerevisiae
}

\author{
Thippeswamy B ${ }^{1 *}$, Shivakumar C.K ${ }^{1}$, Krishnappa $\mathbf{M}^{2}$ \\ ${ }^{1}$ Dept. of Microbiology, Kuvempu University, Jnanasahyadri, Shankaraghatta-577 451, Karnataka, India \\ ${ }^{2}$ Dept. of Applied Botany, Kuvempu University, Jnanasahyadri, Shankaraghatta-577 451, Karnataka, India \\ *Corresponding author E-mail: thippeswamyb205@gmail.com
}

\begin{abstract}
Potential Saccharomyces cerevisiae was isolated from paper effluent for bioremediation of heavy metals. Morphological studies, physiological tests and molecular characterization confirmed isolated yeast colony was $S$. cerevisiae. S. cerevisiae has showed high biosorption of $\mathrm{Cd}^{2+}(67 \%)$, followed by $\mathrm{Pb}^{2+}(61 \%)>\mathrm{Ni}^{2+}(64 \%)>\mathrm{Cr}^{6+}(63 \%)>\mathrm{Cu}^{2+}(57 \%)>\mathrm{Zn}^{2+}(53 \%)$. SEM image of heavy metals treated $S$. cerevisiae showed patches of accumulated heavy metals and ED's spectrum of $S$. cerevisiae treated with heavy metals contained metal peaks. Elemental analysis by EDS confirmed that ion exchange mainly involved in heavy metals biosorption by S. cerevisiae. Optimization of parameters made maximum biosorption of heavy metals. The $\mathrm{pH} 4.0-5.0$, temperature $20-25^{\circ} \mathrm{C}$ and contact time of 60 minute was found optimal for heavy metals biosorption. The metal biosorption was found maximum in single metal system compared to multi metal ions. Pre-treatment method enhanced the metal biosorption. Sorption isotherm studies fit into the model of Langmuir isotherm compared to Freundlich isotherm.
\end{abstract}

Keywords: Biosorption, Heavy metals, Optimization, Saccharomyces cerevisiae, Sorption isotherm.

\section{Introduction}

Lead, mercury, chromium, cadmium, copper, cadmium, nickel and zinc are the major hazardous heavy metals in terms of their environmental load and health effects. Their source is majorly by industrial activity and some natural causes like seepage from rocks and volcanic activity. Toxicity of heavy metals is of considerable concern in India because of their environmental burden (Sahni, 2011).

Most of the heavy metal salts are soluble in water to form aqueous solution and cannot be separated by physico-chemical methods of separation such as chemical precipitation, chemical oxidation or reduction, electrochemical treatment, evaporative recovery, filtration, ion exchange and membrane technologies (Tsekova and Petrov, 2002). These conventional processes used for metal removal are sometimes restricted because of technical and economic constraints (Akar and Tunali, 2006). Metal polluted environment contains fungi, which have adapted to toxic concentration of heavy metals and become metal resistant. Fungi affect the mobility and environmental fate of heavy metals. Saccharomyces sp. accumulates copper and zinc as micronutrients. Along with these micronutrients, it capable to accumulate non-nutrient metals likes nickel, cadmium, lead, chromium in amounts higher than the nutritional requirement (Jaeckel et al., 2005). Metals uptake by living fungi depends on species, culture conditions, metal concentration and cells in the solution (Melgar et al., 2007).

Fungal biomass can be used in the form of nanoparticles successfully for removal of heavy metals from wastewater. The main advantages in use of fungal strain for heavy metal removal from waste water is their size, texture and use as adsorbent without immobilize. Biosorption using fungi can be accomplished by sim ple physical methods without damaging the biosorbents structural integrity and accomplish a high efficiency in the removal of heavy metals from aqueous solution. In biosorption process, the fungal biosorbents have to be easily regenerated and used for number of sorption and desorption cycles without denaturation of biomass with the same removal efficiency (Adeyemi, 2009). Advantages of biosorption process compared to bioaccumulation process includes, growth independent, non-living biomass is not subject to toxicity limitation of cells. The removal of heavy metal ions by fungal biomass has been observed to be more than that by conventional adsorbents such as activated carbon, ion-exchange resins, even algae and seaweeds. Dead biomass can be subjected to physical and chemical treatments to enhance metal biosorption (Sag, 2001).

The objective of our study was to isolate and characterize potential $S$. cerevisiae for biosorption of major toxic heavy metals. Different parameters were optimized for increased biosorption of heavy metals.

\section{Materials and methods}

\subsection{Isolation of saccharomyces cerevisiae}

S. cerevisiae was isolated from paper industrial effluent using Malt extract medium. $50 \mathrm{ml}$ of the medium was dispensed to $250 \mathrm{ml}$ Erlenmeyer flask and $2 \mathrm{ml}$ of 1:10 diluted suspension of untreated paper industrial effluent was added and kept on a rotary shaker for $72 \mathrm{hr}$ at $30^{\circ} \mathrm{C}$. After incubation period, the content was allowed to settle, flask was tilted and a loop of sediment containing yeast cells was streaked on Yeast extract malt extract glucose agar media. Inoculated plates were incubated at room temperature 
for 5-7 days for the growth of yeast colonies. Isolated S. cerevisiae was cultured on Yeast extract peptone dextrose agar (YEPD) media for identification (Saifuddin and Raziah, 2007).

\subsection{Morphological identification}

Growth of S. cerevisiae was confirmed by cultured the isolated colony in Yeast Nitrogen Base medium supplemented with nitrogen source, amino acids, vitamins, trace elements and salts. The morphological identification such as colour and colony characteristics was observed.

\subsection{Physiological characterization}

Physiological identification of $S$. cerevisiae was carried out by performing sugars fermentation test and nitrogen assimilation test (Warren and Shadomy, 1991). Identification of S. cerevisiae was further confirmed based on its utilization of $4 \%$ ethanol as carbon source and development of pseudo-mycelium by slide culture in a Petri dish (Cooke et al., 1960). Physiological tests, such as DGlucose, sucrose, lactose fermentation test, catalase reaction, nitrate growth, ethanol growth, methanol growth, and urea hydrolysis tests were performed for confirmation of $S$. cerevisiae (Sofyan et al., 2000).Isolated pure culture was routinely maintained on YEPD agar media preserved at $4{ }^{\circ} \mathrm{C}$ in refrigerator.

\subsection{Molecular characterization}

Molecular identification of $S$. cerevisiae was performed by gene sequencing of the ITS regions of ribosomal DNA (rDNA). The ITS 1 and ITS 4 region of the rDNA was amplified by polymerase chain reaction (PCR) using ITS 1 and ITS 4 primers. The $\sim 700 \mathrm{bp}$ amplicon was gel eluted and subjected to sequencing. The multiple sequence alignments were developed from the sequence data. ITS sequenceresults were assembled and compared with the sequences from Gene Bank (NCBI; http://www.ncbi.nlm.nih.gov) through Basic Local Alignment Search Tool (BLAST) searches. Distance tree of the isolate was determined and top 10 matches for the sequence derived from the isolate was compared with National Centre for Biotechnology Information (NCBI) blast nucleotide sequence (Marjeta et al., 2002; Nur et al., 2011).

\subsection{Preparation of bio sorbent for heavy metals bio sorption}

The growth medium used for preparation of $S$. cerevisiae biosorbent was Yeast Peptone Glucose (YPG) Medium (Chen and Wang, 2007). Five days old culture of $S$. cerevisiae grown on YEPD agar media plate at $30^{\circ} \mathrm{C}$ was used for inoculation (concentration of cell suspension used was $1 \times 105 \mathrm{CFU} / \mathrm{mL}$ ) in YPG liquid medium. The culture was grown in YPG medium at $30^{\circ} \mathrm{C}$ in conical flask kept on a rotary shaker agitated at $125 \mathrm{rpm}$. After 3-4 days of growth, $S$. cerevisiae was harvested by filtration using $150 \mu \mathrm{m}$ sieve and centrifugation. The harvested biomass was washed with generous amount of deionized water and stored at $20^{\circ} \mathrm{C}$. The biomass of $S$. cerevisiae was treated with $0.5 \mathrm{~N} \mathrm{NaOH}$ for 30 min followed by washing with generous amount of distilled water until the $\mathrm{pH}$ of the solution reached to neutral range of 6.8 7.2. S. cerevisiae biomass was autoclaved at $15 \mathrm{lb} / \mathrm{inch}^{2}$ for 20 min. Autoclaved biomass was dried at $60^{\circ} \mathrm{C}$ for $24 \mathrm{hr}$ in hot air oven to get constant dry weight (Jaeckel et al., 2005; Iqbal et al., 2005).

\subsection{Preparation of metal solution}

Stock metal solution contained $1000 \mathrm{mg} / \mathrm{L}$ concentration of $\mathrm{Ni}(\mathrm{II})$ $\left(\mathrm{NiSO}_{4} \cdot 7 \mathrm{H}_{2} \mathrm{O}\right), \mathrm{Zn}(\mathrm{II}) \quad\left(\mathrm{ZnSO}_{4} \cdot 6 \mathrm{H}_{2} \mathrm{O}\right), \mathrm{Cd}(\mathrm{II})\left(\mathrm{CdCl}_{2}\right), \mathrm{Pb}(\mathrm{II})$ $\left(\mathrm{CH}_{3} \mathrm{COO}\right)_{2} \mathrm{~Pb} .3 \mathrm{H}_{2} \mathrm{O}, \mathrm{Cr}(\mathrm{VI})\left(\mathrm{K}_{2} \mathrm{Cr}_{2} \mathrm{O}_{7}\right)$ and $\mathrm{Cu}(\mathrm{II})\left(\mathrm{CuSO}_{4} \cdot 5 \mathrm{H}_{2} \mathrm{O}\right)$ was prepared by dissolving heavy metals salt in deionised distilled water. The reagents used were of analytical grade supplied by
Merck. The working metal solution of 50, 100, 150 and $200 \mathrm{mgL}$ ${ }^{1}$ concentration was prepared from the stock solution.

\subsection{Biosorption experiments}

Biosorption experiments for $S$. cerevisiae biomass was carried out using $\mathrm{Cr}^{6+}, \mathrm{Cd}^{2+}, \mathrm{Cu}^{2+}, \mathrm{Pb}^{2+}, \mathrm{Zn}^{2+}$ and $\mathrm{Ni}^{2+}$ metal solutions each contained $50,100,150$ and $200 \mathrm{mgL}^{-1}$ metal concentration. A batch experiment of biosorption was performed at constant temperature $\left(25^{\circ} \mathrm{C}\right)$ in Erlenmeyer flasks stirred in a reciprocal shaker with $100 \mathrm{rpm}$ for 02 hours. The equilibrium is reached significantly before two hours. In all sets of experiments, $0.1 \mathrm{gm}$ of pretreated S. cerevisiae biomass was inoculated into $100 \mathrm{ml}$ of each heavy metal solutions for biosorption study.

After biosorption process, the reaction mixtures were filtered to remove particulates and the filtrates were analyzed by Atomic absorption spectrophotometer for the determination of concentration of heavy metals biosorbed. Amount of heavy metals biosorbed by $S$. cerevisiae was calculated from the difference between total amount of heavy metal added and that remained in the supernatant after biosorption process. All the experiments were carried out on a triplicate basis (Kang et al., 2007).

The amount of metal ions (mg) bioadsorbed per gm (dry mass) of biomass was calculated using following equation:

$\mathrm{Q}=\left(\mathrm{C}_{\mathrm{i}}-\mathrm{C}_{\mathrm{f}} / \mathrm{m}\right) \mathrm{V}$

Where $\mathrm{Q}=\mathrm{mg}$ of metal ion bioadsorbed per gm of biomass, $\mathrm{C}_{\mathrm{i}}=$ Initial metal ion concentration $(\mathrm{mg} / \mathrm{L}), \mathrm{C}_{\mathrm{f}}=$ Final metal ion concentration $(\mathrm{mg} / \mathrm{L}), \mathrm{m}=$ Mass of biomass in the reaction mixture $(\mathrm{gm}), \mathrm{V}=$ Volume of the reaction mixture.

The efficiency of heavy metal removal was calculated by following equation from the amount of metal ions adsorbed on biosorbent and amount of metal ions available in solution,

$\%$ removal $=\frac{\text { Heavy metal ions removed }(\mathrm{mg})}{\text { Heavy metal ions available }(\mathrm{mg})} \times 100$

\subsection{Sorption Isotherm analysis}

The equilibrium of sorption is an important factor for evaluating the sorption process as unit operation. In order to investigate the sorption capacity and isotherm, two frequently used equilibrium models, such as Langmuir and Freundlich isotherms were studied and fitted to the data obtained. Initial concentrations of metal solutions used for isotherm analysis was between 50 and $200 \mathrm{mg} / \mathrm{L}$ metal concentration. $0.1 \mathrm{~g}$ of pre-treated $\mathrm{S}$. cerevisiae biomass was mixed into $100 \mathrm{ml}$ of metal solutions for sorption isotherm study.

\subsubsection{Langmuir isotherm}

Langmuir model is probably the best known and most widely applied sorption isotherm. This model defines a monolayer sorption with a homogeneous distribution of sorption sites and sorption energies without interaction between the sorbed molecules. It has produced good agreement with wide variety of experimental data and it can be represented as follows

$\mathrm{q}=\mathrm{q}_{\max } \underline{\mathrm{bC}}$

$1+b_{f}$

Where, $\mathrm{C}$ is equilibrium concentration $\left(\mathrm{m}_{\mathrm{eq}} / \mathrm{L}\right), \mathrm{q}$ is amount of metal ions sorbed $\left(\mathrm{m}_{\mathrm{eq}} / \mathrm{g}\right), \mathrm{q}_{\mathrm{max}}$ is maximum amount of metal ion sorbed per unit weight of biomass to form a complete monolayer $\left(\mathrm{m}_{\mathrm{eq}} / \mathrm{g}\right), \mathrm{b}$ is sorption equilibrium constant $\left(\mathrm{L} / \mathrm{m}_{\mathrm{eq}}\right)$.

The Eq. (3) can be rearranged to the following linear form:

$\underline{\mathrm{C}}=\underline{\mathrm{C}}+\underline{1}$

$\overline{\mathrm{Q}} \mathrm{q}_{\max } \mathrm{q}_{\max } \mathrm{b}$ 


\subsubsection{Freundlich isotherm}

Freundlich empirical model can be applied to non-ideal sorption on heterogeneous surface as well as multilayer sorption and is expressed by Eq. (5). In contrast to Langmuir model, the Freundlich isotherm is more widely used but provides no information on monolayer adsorption capacity.

$\mathrm{q}=\mathrm{k}_{\mathrm{f}} \mathrm{C}^{1 / \mathrm{n}}$

Where, $\mathrm{C}$ is equilibrium concentration $\left(\mathrm{m}_{\mathrm{eq}} / \mathrm{L}\right), \mathrm{q}$ is amount of metal ions sorbed $\left(\mathrm{m}_{\mathrm{eq}} / \mathrm{g}\right), \mathrm{k}_{\mathrm{f}}$ and $\mathrm{n}$ is Freundlich's adsorption constants.

The Eq. (5) is frequently used in the linear form by taking logarithm of both sides as follows:

$\log \mathrm{q}=\log \mathrm{k}_{\mathrm{f}}+1 / \mathrm{n} \log \mathrm{C}$

All experiments were conducted at $27^{\circ} \mathrm{C}$ and result of the data was applied to Equations (4) and (6). In order to determine how well the Freundlich model fitted with experimental data, the plot of log Ce versus $\log q_{e}$ was employed. The calculated values of Langmuir and Freundlich parameters were obtained using least squares method (Pinoa et al., 2006).

\subsection{Scanning electron microscopy (SEM) analysis}

SEM analysis gives morphological characteristics and confirmation of heavy metals accumulation by $S$. cerevisiae. During SEM analysis, a drop of sample was dried on clean silicon wafer and electron conductivity was created externally to the sample by sputtering with gold nanoparticles using a gold sputter coater (Jeo JFC 1100E Ion sputtering device) for 30min. Coated cells were applied with electron acceleration voltage of $20 \mathrm{keV}$ and viewed under Field Emission-SEM (FEI-SIRION, Eindhoven, Netherland).

\subsection{Energy dispersive x-ray spectrometry (EDS) analysis}

ED's analysis was performed to analyse elemental peak and composition including the presence of metal ions on biomass of $S$. cerevisiae before and after treated with heavy metals. EDS of $S$. cerevisiae was taken using NORAN EDS system attached with SEM. Point and region analyses were performed at $15 \mathrm{keV}$. The EDS spectra with metal peaks were recorded during analysis period of 60 second (Xue and $\mathrm{Lu}, 2008$ ).

\subsection{Optimization of parameters}

Batch experiments were performed to study the effect of differen factors such as pretreatment, time period, $\mathrm{pH}$, and temperature, presence of single and multi-metal ions on biosorption process (Kapoor et al., 1999).

\subsubsection{PH}

The optimal $\mathrm{pH}$ value required by $S$. cerevisiae for heavy metals biosorption was determined. $S$. cerevisiae was inoculated into series of $250 \mathrm{ml}$ conical flasks each contained $50 \mathrm{mgL}^{-1}$ of $\mathrm{Cr}^{6+}$, $\mathrm{Cd}^{2+}, \mathrm{Cu}^{2+}, \mathrm{Pb}^{2+}, \mathrm{Zn}^{2+}$ and $\mathrm{Ni}^{2+}$ metal solution. S. cerevisiae inoculated flasks were incubated in rotary shaker incubator at $25^{\circ} \mathrm{C}$ for 120 minutes in $100 \mathrm{rpm}$. The $\mathrm{pH}$ of each metal solution varied from 02 to 07 (02, 03, 04, 05, 06 and 07). $\mathrm{pH}$ of the medium was adjusted using dilute $\mathrm{HCl}$ and $\mathrm{NaOH}$. Amount of heavy metals biosorbed by $S$. cerevisiae biomass was calculated from difference between total amount of heavy metal added and that remained in the supernatant after biosorption. For each $\mathrm{pH}$ point the percentage of metal removal was calculated using equation 1.

\subsubsection{Temperature}

The optimal temperature value required by $S$. cerevisiae for biosorption of heavy metals was determined. $S$. cerevisiae was inoculated into series of $250 \mathrm{ml}$ conical flasks each contained $100 \mathrm{ml}$ of $50 \mathrm{mgL}^{-1} \mathrm{Cr}^{6+}, \mathrm{Cd}^{2+}, \mathrm{Cu}^{2+}, \mathrm{Pb}^{2+}, \mathrm{Zn}^{2+}$ and $\mathrm{Ni}^{2+}$ metal solution. $S$. cerevisiae inoculated metal solutions were incubated at varied temperature of $15^{\circ} \mathrm{C}, 20^{\circ} \mathrm{C}, 25^{\circ} \mathrm{C}, 30^{\circ} \mathrm{C}$, and $35^{\circ} \mathrm{C}$ in rotary shaker incubator for 120 minute at $100 \mathrm{rpm}$. The $\mathrm{pH}$ of metal solution was adjusted to 4.0 using dilute $\mathrm{HCl}$ and $\mathrm{NaOH}$. Amount of heavy metals biosorbed by $S$. cerevisiae biomass was calculated from the difference between total amount of heavy metal added and that remained in the supernatant after biosorption. For each temperature point the percentage of metal removal was calculated using equation 1 .

\subsubsection{Contact time}

The optimal contact time required by $S$. cerevisiae for biosorption of heavy metals was determined. S. cerevisiae was inoculated into series of 250 conical flasks each contained $100 \mathrm{ml}$ of $50 \mathrm{mgL}^{-1}$ concentration $\mathrm{Cr}^{6+}, \mathrm{Cd}^{2+}, \mathrm{Cu}^{2+}, \mathrm{Pb}^{2+}, \mathrm{Zn}^{2+}$ and $\mathrm{Ni}^{2+}$ metal solution. $S$. cerevisiae inoculated metal solutions were incubated at varied incubation period of $30,60,90$, and 120 minute in rotary shaker incubator at $25^{\circ} \mathrm{C}$ of $100 \mathrm{rpm}$. PH of the metal solution was adjusted to 4.0 using dilute $\mathrm{HCl}$ and $\mathrm{NaOH}$. Amount of heavy metals biosorbed by biomass after specific period of incubation was calculated from difference between total amount of heavy metal added and that remained in the supernatant after biosorption. The percentage of metal removal was calculated using equation 1 .

\subsubsection{Single and multi-metal system}

$0.1 \mathrm{~g}$ of $S$. cerevisiae biomass was treated with $50 \mathrm{mgL}$ ${ }^{1}$ concentration of $100 \mathrm{ml} \mathrm{Pb}, \mathrm{Cd}$ and $\mathrm{Cr}$ metal solution. $100 \mathrm{ml}$ of multi-metal solution each contained $50 \mathrm{mgL}^{-1}$ concentration $(\mathrm{Pb}+\mathrm{Cd}),(\mathrm{Pb}+\mathrm{Cr})$ and mixture of $\mathrm{Pb}+\mathrm{Cd}+\mathrm{Cr}$ metal solution was treated with $0.1 \mathrm{~g}$ of $S$. cerevisiae biomass. Amount of heavy metals biosorbed by $S$. cerevisiae biomass was calculated from the difference between total amount of heavy metal added and that remained in supernatant after biosorption.

\section{Results}

\subsection{Isolation and identification of saccharomyces cere- visiae}

Due to continuous enrichment and adaptation in heavy metals polluted environment, potential $S$. cerevisiae was isolated from paper industrial effluent by standard plate count method using Malt extract agar (MEA) media. The presence of moist to waxy colonies was observed on Malt extract agar media. The stereobinocular microscopic observation showed the predominance of budding cells. The suspected yeast isolate was pure cultured and subjected for physiological and molecular identification.

Morphological characters observed for identification of S. cerevisiae were, budding or long oval shaped cells, pseudohyphae, and spore formation. The physiological tests were performed for identification of $S$. cerevisiae (Table 1).

Table 1: Physiological Characterization of Saccharomyces cerevisiae.

\begin{tabular}{lll}
\hline Sl. No & Result & Test \\
\hline 1 & Ellipsoid & Morphology \\
2 & No hyphae & Hyphae \\
3 & Positive & Catalase-reaction \\
4 & Positive & D-Glucose fermentation \\
5 & Positive on & Sucrose fermentation \\
6 & Negative & Lactose fermentation \\
7 & Positive & Citrate growth \\
8 & Positive & Ethanol growth \\
9 & Negative & Methanol growth \\
10 & Positive & Nitrate growth \\
11 & Negative & Urea hydrolysis \\
\hline
\end{tabular}


Physiological tests such as glucose fermentation, galactose fermentation, maltose fermentation, sucrose fermentation, lactose fermentation, nitrate assimilation test and urease utilization tests were performed for the identification of $S$. cerevisiae. D-Glucose and sucrose fermentation medium inoculated with $S$. cerevisiae showed the production of gas in Durham tube and medium colour turned from red to yellow. Whereas the absence of gas production and without change in medium colour was observed in both control medium without inoculated with $S$. cerevisiae and lactose fermentation medium inoculated with $S$. cerevisiae. The $S$. cerevisiae inoculated citrate medium colour was changed from green to blue after incubation period. Citrate medium without inoculated with $S$. cerevisiae was retained their original green colour. The appearance of gas bubbles was observed in catalase test performed with isolated $S$. cerevisiae. Urea hydrolysis test medium inoculated with $S$. cerevisiae was showed the colour change from yellow to red after incubation period.
Molecular identification was performed for the confirmation of $S$. cerevisiae. The sequence of ITS region for $S$. cerevisiae was determined (Table 2).

Table 2: The Sequence of ITS Region for Saccharomyces cerevisiae. 1 aattcctagt aagcgcaagt catcagcttg cgttgattac gtccetgecc ttgtacaca 61 ccgccegtcg ctagtaccga ttgaatggct tagtgaggcc tcaggatctg cttagagaag 121 ggggcaactc catctcagag cggagaattt ggacaaactt ggtcatttag aggaactaaa 181 agtcgtaaca aggtttccgt aggtgaacct gcggaaggat cattaaagaa atttaataat 241 tttgaaaatg gattttttg ttttggcaag agcatgagag cttttactgg gcaagaagac 301 aagagatgga gagtccagcc gggcctagtc ttaagtgcgc ggtcttgcta ggcttgtaag 361 tttctttctt gctattccaa acggtgagag atttctgtgc ttttgttata ggacaattaa 421 aaccgtttca atacaacaca ctgtggagtt ttcatatctt tgcaactttt tctttgggca 481 ttcgagcaat cggggcccag aggtaacaaa cacaaacaat tttatttatt cattaaattt 541 ttgtcaaaaa caagaaattt cgtaactgga aattttaaaa tattaa

The assembly of ITS 1 and ITS 4 sequencing for $S$. cerevisiae was analyzed (Table 3 ).

Table 3: The Assembly of ITS 1 and ITS 4 Sequencing for Saccharomyces cerevisiae

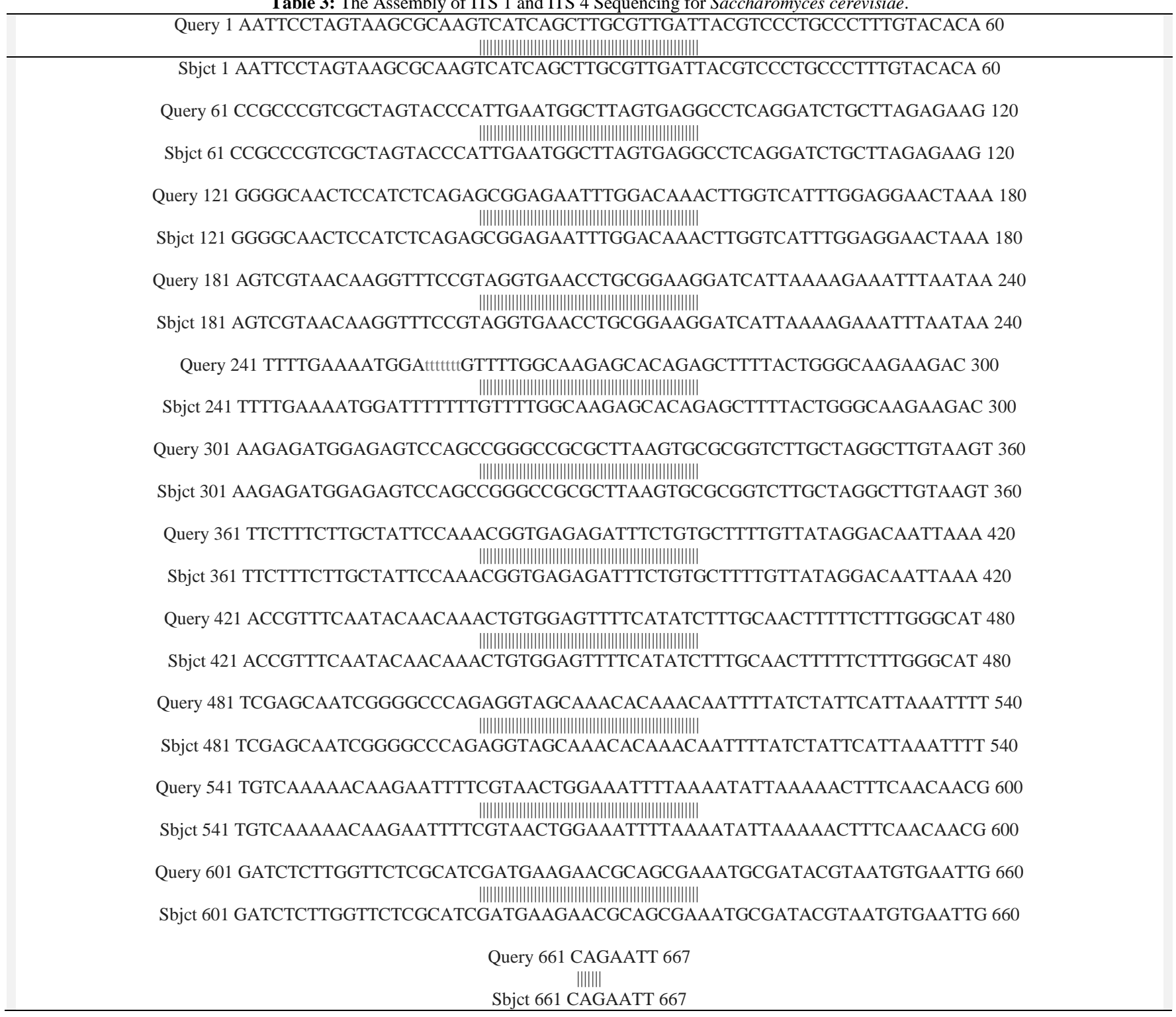

ITS sequencing of isolated yeast culture was showed $100 \%$ identity at $100 \%$ coverage with the sequence from S. cerevisiae during NCBI BLAST nucleotide sequence analysis (Table 4). 
Table 4: Top 10 Matches for the Sequence Derived from Saccharomyces cerevisiae.

\begin{tabular}{|c|c|c|c|c|c|}
\hline \multicolumn{6}{|l|}{$\begin{array}{l}\text { Sequences producing significant alignments: } \\
\text { Select: All None Selected:0 } \\
\text { î Alignments }\end{array}$} \\
\hline Description & $\begin{array}{l}\text { Max } \\
\text { score }\end{array}$ & $\begin{array}{l}\text { Total } \\
\text { score }\end{array}$ & $\begin{array}{l}\text { Query } \\
\text { cover }\end{array}$ & $\begin{array}{c}E \\
\text { value }\end{array}$ & Ident \\
\hline$\square$ S.cerevisiae fragment R-I-D encompassing $18 \mathrm{~S}$ and $5.8 \mathrm{~S}$ ribosomal RNA genes and their Spac & 1232 & 1232 & $100 \%$ & 0.0 & $100 \%$ \\
\hline$\square$ IPA: Saccharomyces cerevisiae S288c chromosome Xll, complete sequence & 1188 & 2377 & $100 \%$ & 0.0 & $99 \%$ \\
\hline$\square$ S.cerevisiae chromosome Xll reading frame ORF YLR154c & 1188 & 1188 & $100 \%$ & 0.0 & $99 \%$ \\
\hline$\square$ Saccharomyces cerevisiae chromosome XII cosmid 9634 & 1188 & 2377 & $100 \%$ & 0.0 & $99 \%$ \\
\hline$\square$ Uncultured compost funqus 18 S rRNA gene (partial), ITS1, 5.8 SRNA gene, ITS2 and 28 SRN & 1182 & 1182 & $99 \%$ & 0.0 & $99 \%$ \\
\hline$\square$ Saccharomyces cerevisiae EC1118 chromosome XII, EC1118 $1 \mathrm{~L} 10$ genomic scaffold, whole c & 1179 & 2358 & $100 \%$ & 0.0 & $99 \%$ \\
\hline$\square$ Uncultured ascomycete ITS region including 18S PRNA gene, ITS1, 5.8S rRNA gene, ITS2 and 2 & $\leqslant 1179$ & 1179 & $99 \%$ & 0.0 & $99 \%$ \\
\hline$\square$ Saccharomyces cerevisiae strain YJM789 35 S ribosomal RNA gene, external transcribed spa & 1173 & 1173 & $100 \%$ & 0.0 & $98 \%$ \\
\hline$\square$ Synthetic construct clone pNOY373 35 S ribosomal RNA, 18 S ribosomal RNA, $5.8 S$ ribosomal $F$ & 1166 & 1166 & $100 \%$ & 0.0 & $98 \%$ \\
\hline aromyces paradoxus NRRL $Y-17217$ genes for $25 S$ rRNA, 5 S rRNA, 18 S rRNA, 5. & 1151 & 1151 & $100 \%$ & 0.0 & $98 \%$ \\
\hline scomycete ITS region including $18 \mathrm{~S} \mathrm{rRNA}$ & 136 & 1136 & $99 \%$ & 0.0 & $97 \%$ \\
\hline & & & $99 \%$ & ח & 970 \\
\hline
\end{tabular}

The distance tree of isolated yeast colony was corresponded to S.cerevisiae (Table 5). There fore the isolated yeast colony was confirmed as Saccharomyces cerevisiae.

Table 5: The Distance Tree of Saccharomyces cerevisiae.

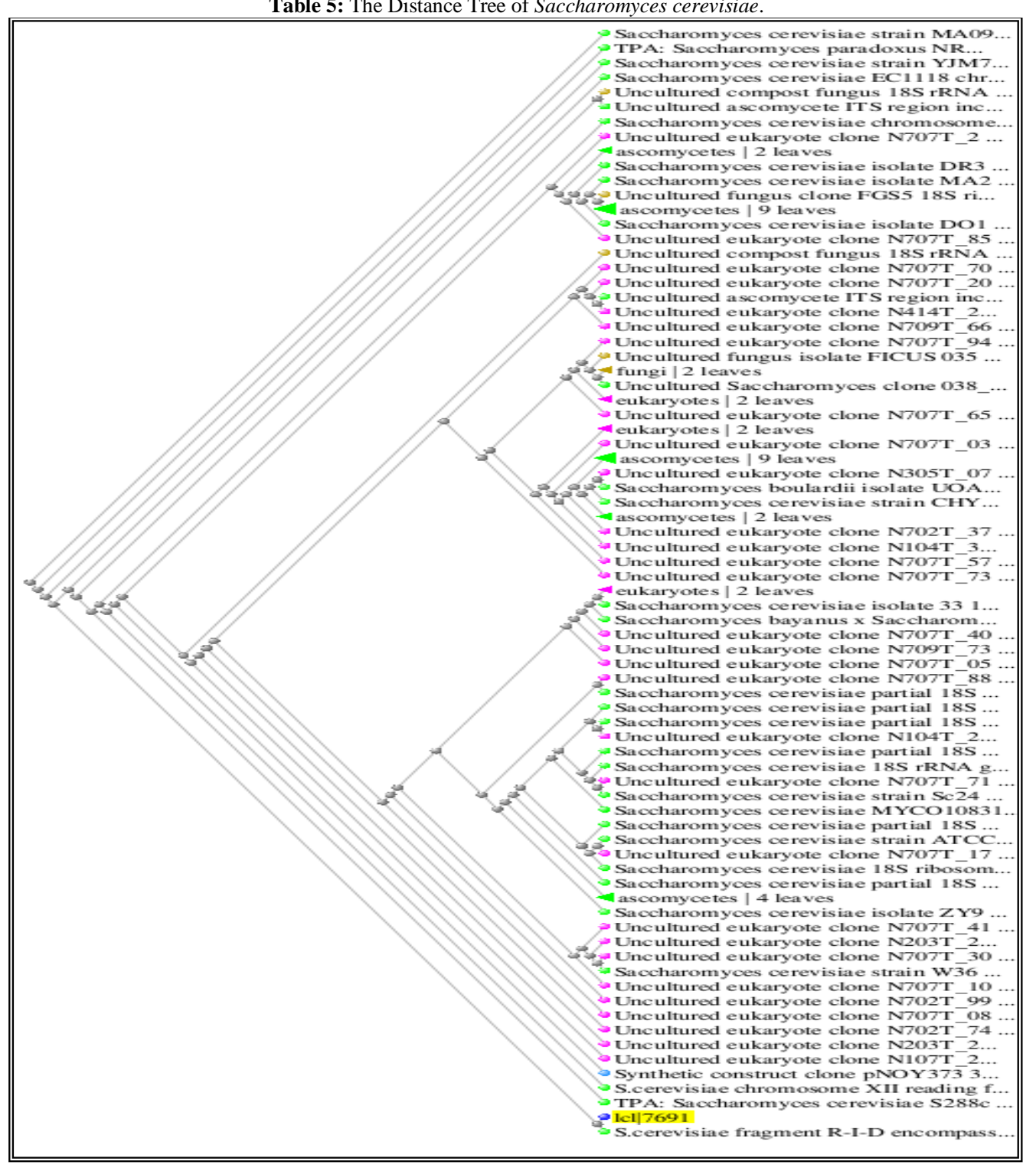




\subsection{Bio sorption of heavy metals}

The percentage of metal biosorption in S. cerevisiae was decreased with increased in treated metal solution concentration to $50,100,150$ and $200 \mathrm{mgL}^{-1}$. S. cerevisiae showed metals biosorption at $50 \mathrm{mgL}^{-1}$ concentration in the order of, $\mathrm{Cd}$ $(67 \%)>\mathrm{Pb}(61 \%)>\mathrm{Ni}(64 \%)>\mathrm{Cr}(63 \%)>\mathrm{Cu}(57 \%)>\mathrm{Zn}(53 \%)$. The biosorption of metals showed by $S$. cerevisiae in $100 \mathrm{mgL}^{-1}$ metals concentration was in the order of, $\mathrm{Cd}(63 \%)>\mathrm{Ni}(59 \%)>\mathrm{Pb}$ $(55 \%)>\mathrm{Cu}(54 \%)>\mathrm{Cr}(53 \%)>\mathrm{Zn}(49 \%)$. The order of metals biosorption observed in $S$. cerevisiae at $150 \mathrm{mgL}^{-1}$ metals concentration was, $\mathrm{Cd}(51 \%)>\mathrm{Ni}(47 \%) \geq \mathrm{Cu}(47 \%)>\mathrm{Pb}(43 \%)>\mathrm{Cr}$ $(41 \%)>\mathrm{Zn}(38 \%)$. The order of metals biosorption observed in $S$. cerevisiae treated with $200 \mathrm{mgL}^{-1}$ concentration was, $\mathrm{Cd}$ $(35 \%)>\mathrm{Ni} \quad(31 \%)>\mathrm{Pb} \quad(29 \%)>\mathrm{Cr} \quad(25 \%)>\mathrm{Cu} \quad(39 \%)>\mathrm{Zn} \quad(21 \%)$ (Figure 1).

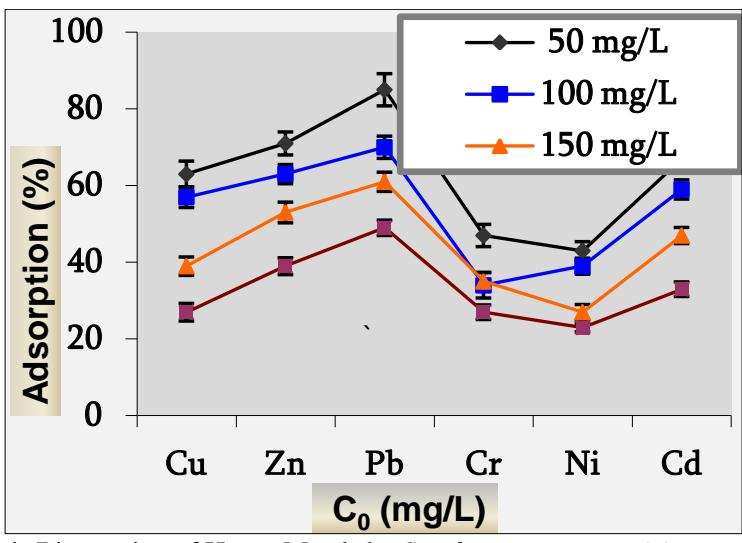

\subsection{Sorption isotherms analysis}

The correlation coefficients of Langmuir and Freundlich isotherms are 0.9979 and 0.8170 respectively (Table 6).

Table 6: Calculated Langmuir and Freundlich Coefficients.

\begin{tabular}{lllll}
\hline & Langmuir parameters & & \multicolumn{2}{c}{ Freundlich parameters } \\
\hline 1 & $\mathrm{q}_{\max }(\mathrm{mg} / \mathrm{g}$ dry biomass $)$ & 155.45 & $\mathrm{n}$ & 2.97 \\
2 & $\mathrm{~b}(\mathrm{~L} / \mathrm{mg})$ & 0.0623 & $\mathrm{k}$ & 16.8 \\
3 & $\mathrm{r}^{2}$ & 0.9979 & $\mathrm{r}^{2}$ & 0.8170 \\
\hline
\end{tabular}

The correlation coefficients of Langmuir isotherm are higher than that of Freundlich model for pre-treated $S$. cerevisiae. This indicates that the Langmuir isotherm for pre-treated $S$. cerevisiae is fitted better and is accepted for this adsorbent. Adsorption process could be well defined by Langmuir isotherm with $\mathrm{r}^{2}$ values 0.9979 .

\subsection{Scanning electron microscopy (SEM)}

Fig. 1: Biosorption of Heavy Metals by Saccharomyces cerevisiae.

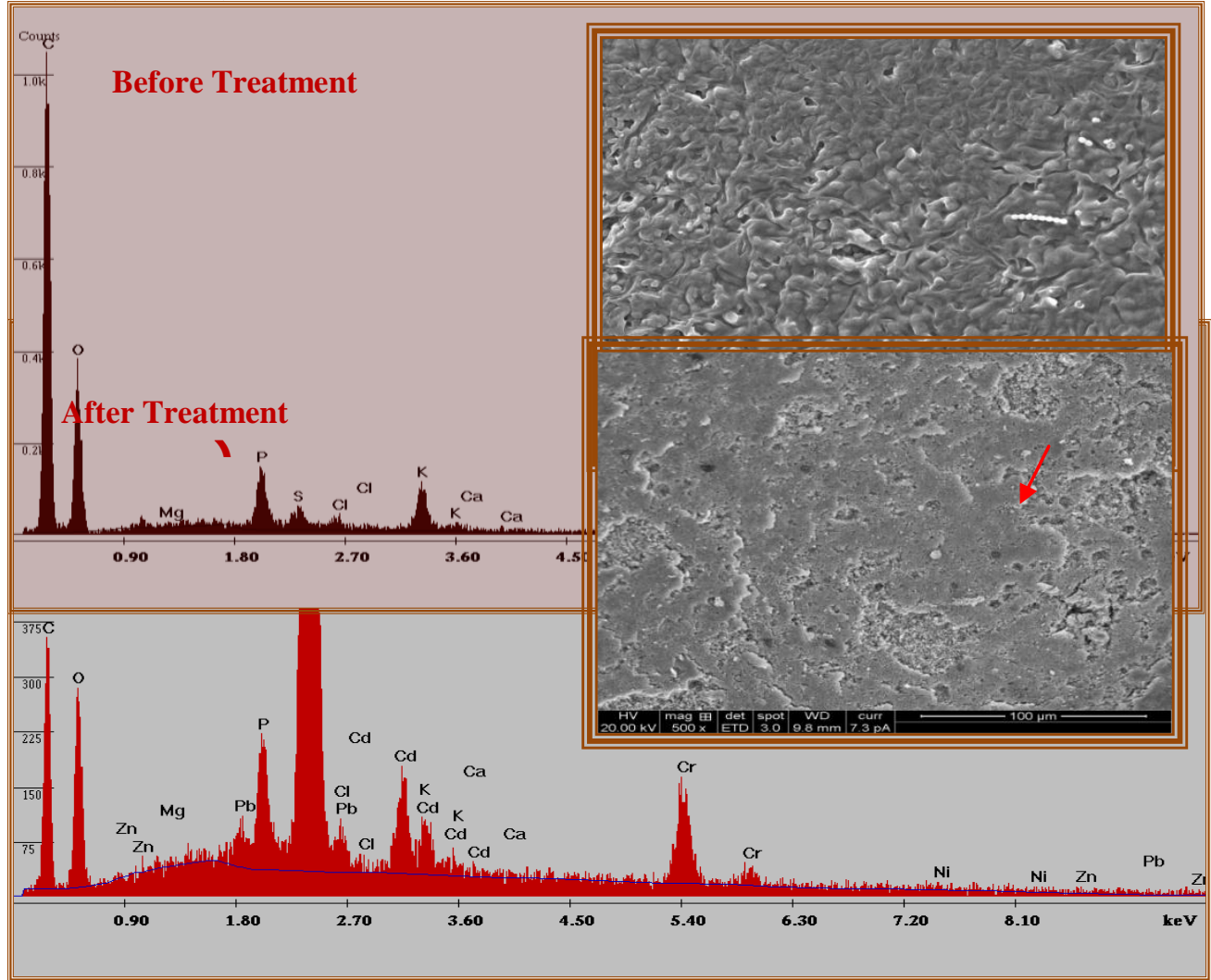

Fig. 2: SEM Photographs and EdS of Saccharomyces cerevisiae Showing Elemental Composition in (A) before (B) after Treated with Heavy Metals.

SEM coupled with EDS analysis was used to study the interaction of metal ions with S. cerevisiae (Figure 2).

SEM analysis revealed that metals was uniformly bound and formed flocculation or patches of heavy metals on S. cerevisiae treated with metals compared to control biomass without treated with metals SEM image of $S$. cerevisiae treated with metals showed altered morphology with dense particles of accumulated heavy metals compared to control showing absence of metal accumulation.

3.5. Energy dispersive x-ray spectrometry (EDS) 
Quantification of metals within $S$. cerevisiae was performed by EDS analysis. When metals treated $S$. cerevisiae was applied for EDS analysis, formation of metals peak was detected compared to control S. cerevisiae without treated with metals. Peak of EDX analysis revealed that a metal ion of $\mathrm{Zn}, \mathrm{Pb}, \mathrm{Cd}, \mathrm{Cr}$ and $\mathrm{Ni}$ has bind to $S$. cerevisiae cell wall at different keV. High ED's spectrum peak of $\mathrm{Pb}^{2+}$ indicates the maximum biosorption of $\mathrm{Pb}^{2+}$ by $S$. cerevisiae compared to other metals. Followed by $\mathrm{Pb}^{2+}$ decreased spectrum peak was observed for other metal ions in the order of, $\mathrm{Cr}>\mathrm{Cd}>\mathrm{Zn} \geq \mathrm{Ni}$.

Elemental composition in EDS for metal treated $S$. cerevisiae was changed after treated with heavy metals (Table 7).

Table 7: Elemental Composition in EDS of Saccharomyces cerevisiae without Treated and Treated with Heavy Metals.

\begin{tabular}{llll}
\hline S1. No. & Elemental composition & Control (wt \%) & $\begin{array}{l}\text { Metal treated } \\
(\text { wt } \%)\end{array}$ \\
\hline 1 & Carbon $(\mathrm{C})$ & 66.80 & 28.59 \\
2 & Oxygen $(\mathrm{O})$ & 22.07 & 9.15 \\
3 & Magnesium $(\mathrm{Mg})$ & 0.23 & 0.08 \\
4 & Phosphorus $(\mathrm{P})$ & 3.63 & 1.19 \\
5 & Sulfur $(\mathrm{S})$ & 1.50 & 1.57 \\
6 & Chlorine $(\mathrm{Cl})$ & 1.02 & 0.77 \\
7 & Potassium $(\mathrm{K})$ & 4.35 & 0.81 \\
8 & Calcium $(\mathrm{Ca})$ & 0.41 & 0.17 \\
9 & Cadmium $(\mathrm{Cd})$ & 0.00 & 4.11 \\
10 & Chromium $(\mathrm{Cr})$ & 0.00 & 4.93 \\
11 & Nickel $(\mathrm{Ni})$ & 0.00 & 1.21 \\
12 & Zinc $(\mathrm{Zn})$ & 0.00 & 0.94 \\
13 & Lead $(\mathrm{Pb})$ & 0.00 & 46.48 \\
Total & & 100.00 & 100.00 \\
\hline
\end{tabular}

The ion exchange mechanism resulted in replacement of $\mathrm{K}, \mathrm{Ca}$, $\mathrm{Mg}$ ions by metal ions such as $\mathrm{Pb}, \mathrm{Cr}, \mathrm{Cd}, \mathrm{Ni}$, and $\mathrm{Zn}$ during biosorption of heavy metals by $S$. cerevisiae. The reduced $\mathrm{C}, \mathrm{O}, \mathrm{Mg}$, $\mathrm{P}, \mathrm{K}, \mathrm{Ca}$ content was observed in control biomass of $S$. cerevisiae without treated with heavy metals compared to metals treated $S$ cerevisiae biomass due to exchange of these ions with heavy metals.

\subsection{Optimization of parameters}

\subsubsection{PH}

Bio sorption of heavy metals observed in $S$. cerevisiae biomass was high at $\mathrm{pH}$ ranging from 4.0 to 5.0 (Figure 3 ).

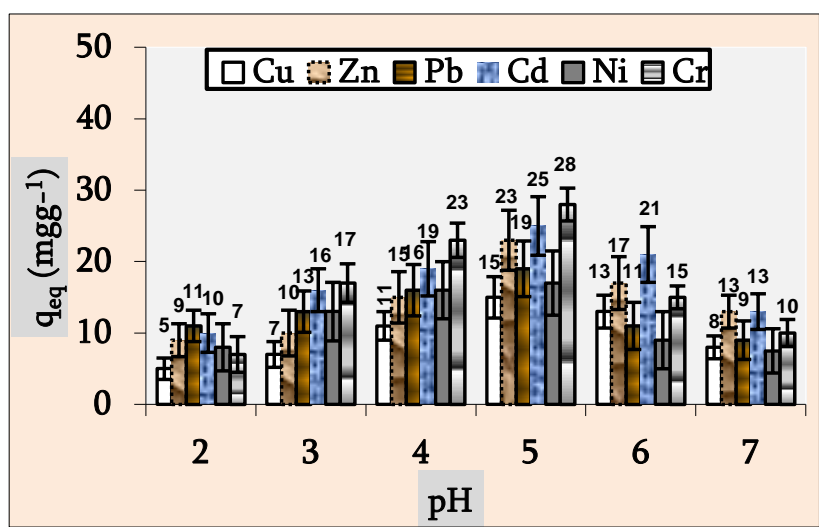

Fig. 3: Biosorption of Heavy Metals by Saccharomyces cerevisiae at Different $\mathrm{pH}$.

The decreased metal biosorption was observed at very low acidic $\mathrm{pH}$ of 2.0 and 3.0. The biosorption ability of $S$. cerevisiae was decreased with increased in $\mathrm{pH}$ to 6.0 and above.

\subsubsection{Temperature}

Temperature is the factor influence on biosorption of heavy metals by $S$. cerevisiae biomass (Figure 4 ).

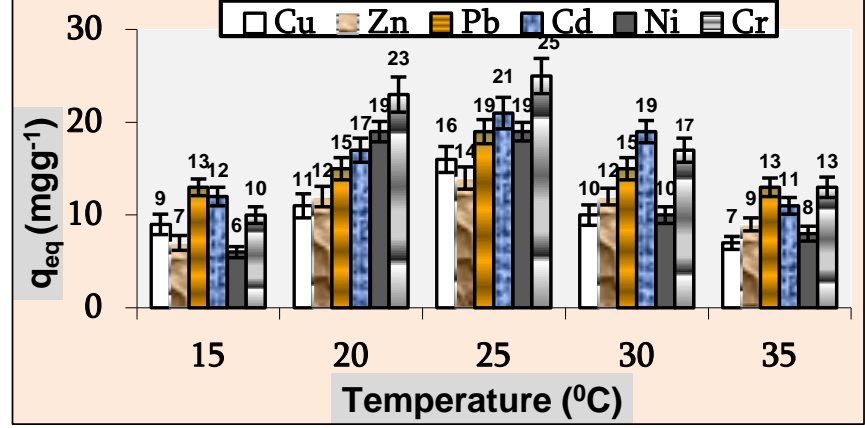

Fig. 4: Biosorption of Heavy Metals by Saccharomyces cerevisiae at Different Temperature.

The observed metal biosorption by $S$. cerevisiae varies at different temperature ranging from 15 to $35^{\circ} \mathrm{C}$. Difference of $05^{\circ} \mathrm{C}$ in metal solution causes increased or decreased metal biosorption. The metals biosorption observed was high in the temperature ranging from 20 to $30^{\circ} \mathrm{C}$. Biosorption of metals was decreased at low temperature between 15 to $20^{\circ} \mathrm{C}$ and in high temperature between 30 to $35^{\circ} \mathrm{C}$.

\subsubsection{Contact time}

Contact time between biomass and metal solution influence on biosorption process. A sufficient contact time should be provided to the biosorbent (S. cerevisiae biomass) for sorption of biosorbate (metal solution). Contact time period between biomass and metal solution was studied from 15 to 120 min (Figure 5).

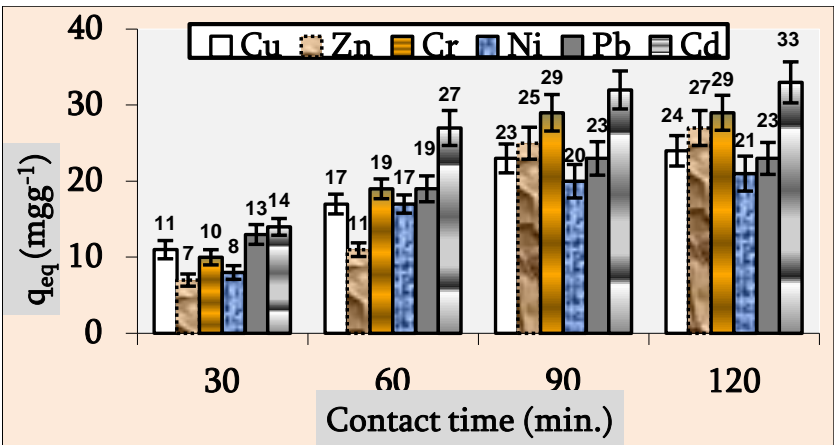

Fig. 5: Bio Sorption of Heavy Metals by Saccharomyces cerevisiae at Different Contact Time.

It was found that heavy metals biosorption by $S$. cerevisiae biomass was high during the contact time period of 60 to $90 \mathrm{~min}$. Metals biosorption observed was less during initial contact time period of 15 to $30 \mathrm{~min}$ and remained constant after $90 \mathrm{~min}$ and above time period.

\subsubsection{Single and multi-metal system}

Bio sorption of heavy metals by $S$. cerevisiae was performed using single, double and multi heavy metals solution of lead, cadmium and chromium (Table 8).

Table 8: Biosorption of Heavy Metals by Fungi in Single and Multi-Metal System.

\begin{tabular}{llllll}
\hline Organism & $\begin{array}{l}\text { Metal } \\
\text { type }\end{array}$ & \multicolumn{4}{l}{ mg of metal ion biosorbed per gram of biomass } \\
\hline & $\begin{array}{l}\text { Single } \\
\text { metal }\end{array}$ & $\mathrm{Pb}+\mathrm{Cr}$ & $\mathrm{Pb}+\mathrm{Cd}$ & $\mathrm{Cr}+\mathrm{Cd}$ & $\begin{array}{l}\mathrm{Pb}+\mathrm{Cr}+\mathrm{C} \\
\mathrm{d}\end{array}$ \\
S.cerevisia & $5.34 \pm 0.1$ & $4.12 \pm 0.1$ & $3.99 \pm 0.1$ & & $1.73 \pm 0.07$ \\
$e$ & $9(\mathrm{~Pb})$ & 9 & 1 & & \\
& $4.23 \pm 0.1$ & $3.71 \pm 0.1$ & & $3.01 \pm 0.1$ & $1.94 \pm 0.09$ \\
& $5(\mathrm{Cr})$ & 3 & & 0 & \\
& $7.93 \pm 0.3$ & & $5.93 \pm 0.2$ & $4.27 \pm 0.2$ & $2.19 \pm 0.15$ \\
& $7(\mathrm{Cd})$ & & 3 & 2 & \\
\hline
\end{tabular}

Note: Results are expressed in Mean \pm Standard Error $(n=3)$

This study determined the effect of more than one heavy metal on biosorption process. The maximum percentage of metal biosorp- 
tion was achieved with single metal solution $(\mathrm{Pb}, \mathrm{Cr}, \mathrm{Cd}) \mathrm{com}$ pared to double $(\mathrm{Pb}+\mathrm{Cd})$ and multi metal solutions $(\mathrm{Pb}+\mathrm{Cd}+\mathrm{Cr})$. The percentage of metal biosorption was decreased with increase in number of metal ions in solution in the order of, $(\mathrm{Pb}, \mathrm{Cr}$, and $\mathrm{Cd})>(\mathrm{Pb}+\mathrm{Cd})>(\mathrm{Pb}+\mathrm{Cr}+\mathrm{Cd})$.

\section{Discussion}

Fungi indigenous to paper mill effluent can be used for bioremediation of heavy metals (Vara et al., 2010; Shanthi et al., 2012). The presence of most dominant yeast genera belonging to $S$. cerevisiae in paper effluent indicates their ability to resist toxic pollutants and used for heavy metals bioremediation studies. It was found that $S$. cerevisiae isolated from highly metal contaminated sites has shown high metal resistance than those isolated from metal uncontaminated sites. Thus, the presence of metal may act as a selective pressure for metal resistance in S. cerevisiae (Madhu et al., 2013).

\subsection{Identification}

The morphological and physiological tests are commonly performed for identification of yeast strains (Kambe et al., 1997). S cerevisiae inoculated into D-Glucose and sucrose medium, $\mathrm{pH}$ indicator (phenol red), which was red at neutral $\mathrm{pH}$ (7.0), turned to yellow in acidic $\mathrm{pH}$ (below 6.8) due to acid production. Nonfermentation ability of lactose and control medium without inoculated with $S$. cerevisiae shows the absence of indicator colour change and acid production. In positive citrate growth test, citrate is the only source of carbon and energy. When citrate is utilized, $\mathrm{CO}_{2}$ generated and combines with sodium to form an alkaline product. This product change the Bromothymol blue indicator colour, from green ( $\mathrm{pH} 6.8$ and below) to blue ( $\mathrm{pH} 6.8$ and above). The enzyme catalase presents in $S$. cerevisiae breaks the hydrogen peroxide into water and oxygen for survive of $S$. cerevisiae. The release of oxygen gas bubbles is an indication for positive catalase test. S. cerevisiae produces urease enzyme, it attacks the carbon bond and liberates ammonia. The produced ammonia raises the $\mathrm{pH}$ of urease medium. Hence the colour of phenol red indicator changes from yellow (pH 6.8) to red (Aneja, 2003).

Yeast has much reduced morphological characters compared to other fungi. Hence, the physiological tests and molecular characterization have been used for identification of S. cerevisiae. The main characteristic features of $S$. cerevisiae are ellipsoid shape cell, have no hyphae, budding cells and do not produce lactosedigesting enzymes. Positive catalase test and negative results of lactose fermentation confirmed the presence of $S$. cerevisiae (Kurtzman, 1988).Morphological and physiological tests have commonly been used for phenotypic characterization of yeast species. These methods are often unreliable due to strain variability and therefore do not allow differentiation between yeast strains belonging to the same species. Genetic characterization using molecular techniques provides more powerful method for identification of $S$. cerevisiae compared to physiological and morphological tests (Marjeta et al., 2002).

Species conformation was carried out by ITS sequence using ITS 1 and ITS 4 primers and produced single pattern band around 524 to $626 \mathrm{bp}$. The BLAST result through Gene Bank showed the regions of local similarity between sequences of yeast isolate with S. cerevisiae (Nur et al., 2011).

\subsection{Scanning electron microscopy (SEM) and energy dispersive $x$-ray spectrometry (EDS)}

All treated metals biosorbed by $S$. cerevisiae biomass because the biosorption process is less dependent on factors like metabolic energy, substrate composition, enzymatic system and presence of metabolic inhibitors. The technique of SEM coupled with EDS analysis has been confirmed that chelation, ion exchange, adsorption and precipitation are involved in metal biosorption by $S$. cere- visiae due to multi-laminate, micro febrile cell wall structure (Dostalek et al., 2004). EDS analysis confirmed that ion exchange is one of the most predominant mechanism involved in heavy metals biosorption by $S$. cerevisiae. Presence of mannan-glucan cell wall with positively charged chitin and negatively charged phosphate and glucuronic acid residues offer extensive possibilities for binding of metals through ion exchange and coordination in S. cerevisiae (Sag, 2001).These functional groups have higher and more covalent affinity towards toxic transition metals like $\mathrm{Cu}$, $\mathrm{Cd}, \mathrm{Co}$, Ni compared to alkali earth metals such as $\mathrm{Na}, \mathrm{K}, \mathrm{Ca}$ (Rao et al., 2005). Additional support for ion exchange is that the metal biosorption capacity of $S$. cerevisiae decreased with decreasing in $\mathrm{pH}$ due to metal cations and protons compete for same binding sites on the cell wall as pH decreased (Shadia et al., 2012).

EDS is useful for qualitative analysis because complete spectrum of elements present in specimen can be obtained very quickly. The accelerating voltage used in EDS indicates types of elements present on specimen. Materials containing heavy elements give higher detection limits in EDS due to higher background. Therefore the presence of heavy metals can be easily detected in EDS analysis (Goldstein et al., 2003).The cellular content in EDS analysis revealed that $S$. cerevisiae cell wall is rich in $\mathrm{C}, \mathrm{O}, \mathrm{K}$ and $\mathrm{P}$ contents to enhance the metal accumulation. ED's analysis of metal treated $\mathrm{S}$. cerevisiae is rich in metal ions due to ion exchange with other ions (Engl and Kunz, 1995). The SEM can be used for element mapping, if X-ray spectrometer is added. This made considerable significance for identification of elements by overlap in the functions of these instruments (Huma et al., 2001).

\subsection{Biosorption}

Metal ion concentrations, adsorption time, $\mathrm{pH}$ and co-ions have great influence on metal biosorption. The kinetics of metal binding indicated that biosorption is rapidly reached $60 \%$ of the final uptake value within 15 min of contact period (Engl and Kunz, 1995). The metal uptake capacity was significantly affected in the presence of the co-existed ions. The presence of metal ions in twocomponent aqueous solution decreases metal uptake capacity of fungi. Metal biosorption in multi-metals aqueous solution is found less compared to single metal solution (Abhishek, et al., 2010).

This confirmed that extent of metal sorption depended on metal chemistry, affinity for binding sites and type of metal. The order of metal biosorption in a multi-metal system could be predicted well based on Langmuir parameters evaluated in binary metal system (Sarabjeet and Dinesh, 2007). High metal biosorption was obtained at initial metal concentration ranging from $50-100 \mathrm{mgL}^{-1}$ at $30^{\circ} \mathrm{C}$ temperature and $\mathrm{pH} 5.0$ (Ozer and Ozer, 2003).

Dark melanin pigment and extracellular polymers located in $S$. cerevisiae can reduce the toxic effect of heavy metals. This property is of great importance to $S$. cerevisiae growing in polluted habitats for binding and removal of heavy metals. Therefore, yeast tolerance towards heavy metals is of high importance for their application in heavy metals bioremediation (Shazia et al., 2012). Biomass of $S$. cerevisiae can be procured from the existing fermentation industries, which is essentially a waste after fermentation. As non-living biomass behave as an ion exchange, the process is very rapid and takes place between few minutes to few hours. Metal loading on biomass is often very high, leading to very efficient metal uptake. Due to non-living cells, processing conditions are not restricted to those conducive for the growth of cells. A wider range of operating conditions such as $\mathrm{pH}$, temperature and metal concentration is possible. No aseptic conditions are required for biosorption process. Metal can be desorbed easily from the biomass and can be reused. Once metals bound, acts as a template for further heterogeneous nucleation and crystal growth (Srivastava and Thakur, 2006).

$\mathrm{S}$. cerevisiae that have been heat killed and pre-treated have lost their membrane integrity and this intern helps in exposure of various functional groups on the surface of $S$. cerevisiae for binding and removal of heavy metals. Effluents containing multiple heavy metals like $\mathrm{Cu}, \mathrm{Ni}, \mathrm{Zn}, \mathrm{Cr}$, and $\mathrm{Zn}$ can be effectively treated using 
S. cerevisiae. The external layer of $S$. cerevisiae influences global electric charge, hydrophobicity and wall porosity for the macromolecules. The presence of macromolecules allows yeast cells to display several functional groups that can interact with heavy metals. The external layer of the cell wall, which is wall porosity for macromolecules and mannoproteic in nature, seems to be more important for metal accumulation than the innermost layer of glucans. SEM results confirmed that several macromolecules present on yeast cell surface allow the yeast cells to bind with heavy metals to form flocculation of heavy metals. Formation of cell aggregate or biofilms during biosorption of heavy metals was confirmed by SEM image. Presence of external energy source like glucose for preparation of biosorbent greatly enhanced three fold biosorption processes. These features made yeast cells as desirable for heavy metals biosorption (Soares and Soares, 2012).

Metabolism-independent binding of metal ions in yeast cell is usually rapid and large amounts of heavy metals may be bound. The heavy metals biosorption capacity of dead biomass may be greater, than that of living cells at low metal concentrations. With increase in metal concentrations from $50 \mathrm{mgL}^{-1}$ to $200 \mathrm{mgL}^{-1}$, the percentage of biosorption decreased due to increased electrostatic interactions of metal ions on cell surface (Yun-guo et al., 2006). S. cerevisiae can successfully adsorb toxic $\mathrm{Zn}^{2+}, \mathrm{Cu}^{2+}, \mathrm{Cd}^{2+}, \mathrm{Pb}^{2+}$, $\mathrm{Ni}^{2+}, \mathrm{Fe}^{2+}, \mathrm{Mn}^{2+}$ and $\mathrm{Cu}^{6+}$ metals from aqueous solution compared to other fungi, which are in their metals biosorption (Ahluwalia and Goyal, 2007). Biosorption of metals decreases with increase in number of metal ions due to number of metal ions compete for same binding sites available on biomass surface. Lack of metal binding sites also results in decreased metal biosorption (Shazia et al., 2012).

\subsection{Effect of $\mathrm{pH}$}

The dependence of metal uptake on $\mathrm{pH}$ is related to both surface functional groups present on biomass and metal chemistry in solution. At low pH of 2.0-3.0, the surface ligands are closely associated with the hydronium ions $\left(\mathrm{H}_{3} \mathrm{O}^{+}\right)$and restricted the approach of metal cations. As a result of repulsive force causes decreased metal sorption takes place at low $\mathrm{pH}$. The $\mathrm{pH}$ dependency of metals uptake by $S$. cerevisiae biomass is due to association and dissociation of certain functional groups like carboxyl and hydroxyl groups. At low $\mathrm{pH}$, most of the carboxylic groups is not dissociated and cannot bind the metal ions to fungal cell wall (Choudhary and Sar, 2009).

At high $\mathrm{pH}$ value metals get precipitate, cadmium ions precipitate as $\mathrm{Cd}(\mathrm{OH})_{2}$ and trivalent chromium ions precipitate as $\mathrm{Cr}(\mathrm{OH})_{3}$. This causes very low biosorption of metal ions in high $\mathrm{pH}$ value (Pinoa et al., 2006). The metal binding sites on cell surface and availability of metal ions in solution are affected by $\mathrm{pH}$. At low $\mathrm{pH}$, the cell surface sites are closely linked to the $\mathrm{H}^{+}$ions, thereby making these unavailable for metal cations. However, with in crease in the $\mathrm{pH}$, there is an increase in ligand with negative charges which results in increased binding of cations. The increase in $\mathrm{pH}$ causes increased negative charge on cell surface which favoured electrochemical attraction and adsorption of metals (Johncy et al., 2010). The optimal $\mathrm{pH}$ for biosorption of heavy metals by fungal biomass is between 5.0-5.2 (Shankar et al., 2007).

Ionic strength influences the adsorption of solute on biomass surface. When two phases, e.g. biomass surface and solute in aqueous solution are in contact, they are bound to be surrounded by an electrical double layer owing to electrostatic interaction. Thus, adsorption decreases with increase in ionic strength. Some inorganic ions such as chloride, may form complexes with some metal ions and thereby affect the sorption process. The dosage of a biosorbent strongly influences the extent of biosorption (Price et al., 2001).

\subsection{Effect of temperature}

Temperature affects biosorption only to a lesser extent within the range from 20 to $35^{\circ} \mathrm{C}$ (Veglio and Beolchini, 1997). Higher temperatures usually enhance sorption due to increased surface activity and kinetic energy of the solute (Sag and Kutsal, 2000). Physical damage to the biosorbent and exothermic nature of some adsorption processes reduce biosorption capacity of the biomass in high temperature (Srivastava and Thakur, 2006). It is always desirable to conduct biosorption at room temperature, as this condition is easy to replicate (Vijayaraghavan and Yeoung, 2008).

\subsection{Sorption Isotherms}

Freundlich and Langmuir models are used to fit the experimental data in order to assess maximum adsorption capacity correspond to biomass surface saturation and adsorption intensity of sorbent towards the biomass. These classical adsorption models have been extensively used to describe the equilibrium established between adsorbed metal ions on the biomass $\left(\mathrm{q}_{\mathrm{eq}}\right)$ and metal ions remaining in solution $\left(\mathrm{C}_{\mathrm{eq}}\right)$ at constant temperature (Ho et al., 2000). Monolayer biosorption as well as heterogeneous surface conditions may co-exist under applied experimental conditions. Hence, the overall sorption of metal ions on biomass may involve more than one mechanism such as ion exchange, surface complexation and electrostatic attraction. The value of correlation coefficient $\left(r^{2}\right)$ presented that the Langmuir model adjusts the experimental data very well for the adsorption of metal by pre-treated S. cerevisiae biomass. The equilibrium time is one of the important parameter in biosorption

The distribution of bonded ions on the sorbent surface is greater than unity, indicating that the metal ions are favourably adsorbed under all the examined experimental conditions. Both isotherms can be used to model biosorption data from dilute aqueous solutions. It is suggested that the sorption of metals is more correctly described by more than one model kinetic analyses. This not only allows the estimation of sorption rates but also lead to suitable rate expressions characteristic of possible reaction mechanisms (Smith, 1996).

\section{Conclusion}

Saccharomyces cerevisiae has shown great potential to treat all major toxic heavy metals through biosorption. Non-living biomass exhibited higher metal uptake ability. The potential advantages in use of non-living fungal biomass compared to already-existing treatment technologies for metals removal is, easily and certainly can be applied for treatment of large scale heavy metals without the generation of toxic sludge. Non-living biomass also eliminate the problem of metal toxicity, possible adverse operating conditions, economic burden of culture maintenance and nutrient supply for the living cells. The selection of $S$. cerevisiae for biosorption study made easy genetic manipulation to increase the biosroption of heavy metals.

\section{Acknowledgement}

The authors would like to thanks to Department of Microbiology, Kuvempu University for providing laboratory facilities and generous support.

\section{References}

[1] Abhishek M, Durba D, Sushil KM, Raktim B, Tapan KD, Naoual B \& Anisur, RK (2010), Tolerance of arsenate-induced stress in Aspergillus niger, a possible candidate for bioremediation. Ecotoxicology and Environmental Safety
http://dx.doi.org/10.1016/j.ecoenv.2009.09.015.

[2] Adeyemi AO (2009). Bioaccumulation of arsenic by fungi. American Journal of Environmental Science 05, 364-370. http://dx.doi.org/10.3844/ajessp.2009.364.370. 
[3] Ahluwalia SS \& Goyal D (2007), Microbial and plant derived biomass for removal of heavy metal from wastewater. Bioresource Technology 98, 2243-2257. http://dx.doi.org/10.1016/j.biortech.2005.12.006.

[4] Akar T \& Tunali S (2006), Biosorption characteristics of Aspergillus flavus biomass for removal of $\mathrm{Pb}(\mathrm{II})$ and $\mathrm{Cu}$ (II) ions from an aqueous solution. Bioresource Technology 97, 1780-1787. http://dx.doi.org/10.1016/j.biortech.2005.09.009.

[5] Aneja KR (2003), .Experiments in Microbiology, Plant Pathology and Biotechnology, New age international publishers. 04, 257-290.

[6] Chen C \& Wang J (2007), Response of Saccharomyces cerevisiae to lead ion stress. Applied Microbial Biotechnology 74, 683-687. http://dx.doi.org/10.1007/s00253-006-0678-x.

[7] Choudhary S \& Sar P (2009), Characterization of a metal resistant Pseudomonas sp. isolated from uranimum mine for its potential in heavy metal $\left(\mathrm{Ni}^{2+}, \mathrm{Co}^{2+}, \mathrm{Cu}^{2+}\right.$, and $\left.\mathrm{Cd}^{2+}\right)$ sequestration. Bioresource Technology 100 , http://dx.doi.org/10.1016/j.biortech.2008.12.015.

[8] Cooke WB, Phaff HJ, Miller MW, Shifrine M \& Knapp EP (1960), Yeasts in polluted water and sewage. Mycologia 52, 210-230. http://dx.doi.org/10.2307/3756007.

[9] Dostalek P, Patzak M \& Matejka P (2004), Influence of specific growth limitation on biosorption of heavy metals by Saccharomyces cerevisiae. International Biodeterioration and Biodegradation 54 203-207. http://dx.doi.org/10.1016/j.ibiod.2004.03.013.

[10]Engl A \& Kunz B (1995), Biosorption of heavy metals by Saccharomyces cerevisiae: effect of nutrient conditions. Journal of Chemical

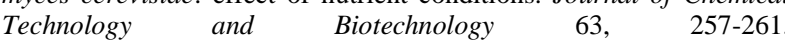
http://dx.doi.org/10.1002/jctb.280630310.

[11]Goldstein JI, Newbury, DE, Joy, DC, Lyman CE, Echlin O, Lifshin E, Sawyer L \& Michael JR (2003), Scanning electron microscopy and Xray microanalysis. $3^{\text {rd }}$ Edition, Kluwer Academia/Plenum Publishers, New York.

[12]Ho YS, Ng JCY \& Mckay G (2000), 'Kinetics of pollutant sorption by biosorbents: a review'. Separation and Purification Methods 29, 189232. http://dx.doi.org/10.1081/SPM-100100009.

[13]Huma R, Haq N \& Bhatti TM (2001), Bioleaching studies of bauxite ore using Aspergillus nige. Journal of Biological Sciences 01, 501504.

[14]Iqbal A, Shaheen Z \& Farah A (2005), Heavy metal biosorption potential of Aspergillus and Rhizopussp. Isolated from wastewater treated soil. Journal of Applied Sciences and Environmental Management $09,123-126$.

[15] Jaeckel P, Krauss GJ \& Krauss G (2005), Cadmium and zinc response of the fungi Heliscus lugdunensis and Verticillium cf. Alboatrum isolated from highly polluted water. Science of the Total Environment 346, 274-279. http://dx.doi.org/10.1016/j.scitotenv.2004.12.082.

[16]Johncy MR, Hemambika B, Hemapriya J \& Rajesh KV (2010), Comparative assessment of heavy metal removal by immobilized and dead bacterial cells: A biosorption approach. African Journal of Environmental Science and Technology 04, 77-83.

[17]Kambe HH, Sugawara A, Yoda K, Kitamoto K \& Yamasaki M (1997), Isolation and characterization of nickel-accumulating yeasts Applied Microbial Biotechnology 48, 373-378. http://dx.doi.org/10.1007/s002530051065

[18]Kang SY, Lee JU \& Kim KW (2007), Biosorption of Cr (III) and Cr (VI) onto the cell surface of Pseudomonas aeruginosa, Biochemical Engineering Journal 36, 54-58. http://dx.doi.org/10.1016/j.bej.2006.06.005.

[19]Kapoor A, Viraraghavan T \& Cullimor DR (1999), Removal of heavy metals using the fungus Aspergillus niger. Bioresource Technology 70, 95-104. http://dx.doi.org/10.1016/S0960-8524 (98)00192-8.

[20]Kurtzman CP (1988), Identification and taxonomy of yeast. In: Kirsop, B.E. and C.P. Kurtzman (Eds). Living Resources for Biotechnology: Yeast. Cambridge University Press, New York: 98-140.

[21]Madhu P, Srivastava \& Neeta S (2013), Biosorption of copper zinc and chromium from aqueous solution by fungal strains. Journal of Chemistry and Chemical Science 03, 131-139.

[22]Melgar MJ, Alonso J \& Garcia MA (2007), Removal of toxic metals from aqueous solutions by fungal biomass of Agaricus Macrospores. Science of the Total Environment 385, 12-19. http://dx.doi.org/10.1016/j.scitotenv.2007.07.011.

[23]Marjeta R, Neza C \& Peter R (2002), Identification and characterization of yeast isolates from pharmaceutical waste water. Food Technology and Biotechnology 40, 79-84

[24]Nur LI, Nur AIMZ \& Soon GT (2011), Tolerance and biosorption of copper $(\mathrm{Cu})$ and lead $(\mathrm{Pb})$ by filamentous fungi isolated from a freshwater ecosystem. Journal of Environmental Sciences 23, 824-830. http://dx.doi.org/10.1016/S1001-0742(10)60475-5

[25] Ozer a \& Ozer D (2003), Comparative study of the biosorption of $\mathrm{Pb}$ (II), Ni (II) and Cr (VI) ions onto Saccharomyces cerevisiae: Deter- mination of biosorption heats. Journal of Hazardous Material 100 , 219-229. http://dx.doi.org/10.1016/S0304-3894 (03)00109-2.

[26]Pinoa GH, Mesquitaa DE, Torema ML \& Pinto GAS (2006), Biosorption of Heavy Metals by Powder of Green Coconut Shell. Separation Science and Technology 41, 3141-3153. http://dx.doi.org/10.1080/01496390600851640.

[27]Price MS, Classen JJ \& Payne GA (2001), Aspergillus niger absorbs copper and zinc from swine wastewater. Bioresource Technology77, 41-49. http://dx.doi.org/10.1016/S0960-8524 (00)00135-8.

[28]Rao KR, Rashmi K, Latha JNL \& Mohan PM (2005), Bioremediation of toxic metal ions using biomass of Aspergillus fumigates from fermentative waste. Indian Journal of Biotechnology 04, 139-143.

[29]Sag Y (2001), Biosorption of heavy metals by fungal biomass and modelling of fungal biosorption: a review. Separation and Purification Methods 30, 01-48. http://dx.doi.org/10.1081/SPM-100102984.

[30]Sag Y \& Kutsal T (2000), Determination of the biosorption activation energies of heavy metal ions on Zoogloea raigera and Rhizopus arrhizus. Process Biochemistry 35, 801-807. http://dx.doi.org/10.1016/S0032-9592 (99)00154-5.

[31]Sahni SK (2011), Hazardous metals and minerals pollution in India. Indian National Science Academy. Angkor Publishers (P) Ltd., New Delhi: 29

[32] Saifuddin N \& Raziah AZ (2007), Removal of heavy metals from industrial effluent using Saccharomyces cerevisiae (Baker's yeast) immobilized in chitosan lignosulphonate matrix. Journal of Applied Science Research 03, 2091-2099.

[33] Sarabjeet SA \& Dinesh G (2007), Microbial and plant derived biomass for removal of heavy metals from wastewater. Bioresource Technology 98 2243-2257. http://dx.doi.org/10.1016/j.biortech.2005.12.006

[34] Shadia MA, Hoda AH \& Foukia EM (2012), Acidic exo polysaccharide flocculant produced by the fungus Mucorrouxii using BeetMolasses. Research in Biotechnology 03, 01-13.

[35] Shankar C, Sridevi D, Joonhong P, Michael D \& Kaliannan T (2007), Biosorption of chromium and nickel by heavy metal resistant fungal and bacterial isolates. Journal of Hazardous Materials 146, 270-277. http://dx.doi.org/10.1016/j.jhazmat.2006.12.017.

[36] Shanthi J, Krubakaran CTB \& Balagurunathan R (2012), Characterization and isolation of paper mill effluent degrading microorganisms Journal of Chemical and Pharmaceutical Research 04, 4436-4439.

[37]Shazia I, Kousar P, Jawaria U, Kinat N, Noreen A, Sana A \& Iftikhar A (2012), Heavy metal tolerance of filamentous fungal strains isolated from soil irrigated with industrial waste water. Biologija 58, 107-116.

[38] Smith EH (1996), Uptake of heavy metals in batch systems by a recycled iron-bearing material, Water Research 30, 2424-2434 http://dx.doi.org/10.1016/0043-1354 (96)00105-4

[39] Soares EV \& Soares HMVM (2012), Bioremediation of industria effluents containing heavy metals using brewing cells of Saccharomyces cerevisiae as a green technology: a review. Environment Science Pollution Research 19, 1066-1083. http://dx.doi.org/10.1007/s11356011-0671-5.

[40]Sofyan A, Utomo R, Yusiati LM \& Widyastuti Y (2000), Isolation and identification of lactic acid bacteria and Saccharomyces cerevisiaefrom natural sources as feed-silage inoculants.Proceeding: The 3rd International Conference of Indonesian Society for Lactic Acid Bacteria (3rd IC-ISLAB.). Better Life with Lactic Acid Bacteria: Exploring Novel Functions of Lactic Acid Bacteria.

[41]Srivastava S \& Thakur IS (2006), Isolation and process parameter optimization of Aspergillus sp. For removal of chromium from tannery effluent. Bioresource Technology97, 1167-1173. http://dx.doi.org/10.1016/j.biortech.2005.05.012.

[42] Tsekova K \& Petrov G (2002), Removal of heavy metals from aquous solution using Rhizopus delmar Mycelia in free and polyuretanebound form. Z. Naturforsch 57, 629-633.

[43] Vara S, Avasn YM \& Mukkanti K (2010), Potential fungi for bioremediation of industrial effluents. Bioresources 05, 08-22.

[44]Vijayaraghavan, K \& Yeoung SY (2008), Bacterial biosorbents and biosorption.Biotechnology Advances 26, 266-291. http://dx.doi.org/10.1016/j.biotechadv.2008.02.002.

[45] Veglio F \& Beolcini F (1997), Removal of metals by biosorption: A review. Hydrometallurgy 44, http://dx.doi.org/10.1016/S0304-386X (96)00059-X.

[46]Warren NG \& Shadomy HJ (1991), Yeast of medical importance, In Balows, A., Hausler, W.J., Herrmann, K.L., Isenberg, H.D., Shadomy, H.J. (Eds.). Manual of Clinical Microbiology $5^{\text {th }}$ ed. American Society for Microbiology, Washington, D.C: 617-629.

[47]Xue Q \& Lu S (2008), Microstructure of ferrospheres in fly ashes: SEM, EDX and ESEM analysis. Journal of Zhejiang University SCIENCE A, 09, 1595-1600. http://dx.doi.org/10.1631/jzus.A0820051. 